\title{
Study of the Microbial Composition and Comparative Biogas Production from Fresh, Dried and Cow-Dung Seeded Pumpkin (Cucurbita maxima) Residue
}

\section{Okoh Ezennia Valentine Charles ${ }^{1,2}$}

${ }^{1}$ Department of Pure and Applied Chemistry, Faculty of Science, Usmanu Danfodiyo University Sokoto, Sokoto State, Nigeria; e-mail: okoh.ezennia@gmail.com

${ }^{2}$ Sokoto Energy Research Centre, Energy Commission of Nigeria, Nigeria

\begin{abstract}
The research study was aimed at identifying the microorganism(s) associated with biogas production as well as comparing the biogas production potential of the fresh, dried and cow dung seeded pumpkin wastes as substrate. The samples were procured from different fruit seller locations within Sokoto metropolis and the study conducted within a period of five weeks (35 days). Standard microbiological methods were used for isolating and identifying the microbes while fabricated anaerobic bio-digesters were used to ascertain the biogas production from the substrates. Analysis revealed that the $\mathrm{pH}$ varied between 6.30 to 7.20 and 5.0 to 6.2 before and during/after the anaerobic digestion respectively. Anaerobic bacteria isolated were identified as Enterobacter spp and Escherichia coli. The results showed 4850, 1430 and $1770 \mathrm{~cm}^{3}$ biogas production from the fresh, dried and cow dung co-seeded substrates respectively during the retention periods with a calorific value of $4773 \mathrm{kcal} / \mathrm{kg}$. The volume of biogas produced varied significantly $(\mathrm{p}<0.05)$ between the substrate treatments and the digestion intervals (days). GC-MS analysis confirmed the identity of the produced methane. This study confirmed the role of bacteria as well as the capability of the substrate to produce biogas production in an in vitro bio-digester system.
\end{abstract}

\section{Introduction}

Developing countries like Nigeria not only faces energy scarcity which present challenges to human health and economic development but is also plagued with

Received: November 4, 2020; Accepted: December 22, 2020

Keywords and phrases: biogas, digester, methanogens, pumpkin substrate.

Copyright (C) 2021 Okoh Ezennia Valentine Charles. This is an open access article distributed under the Creative Commons Attribution License, which permits unrestricted use, distribution, and reproduction in any medium, provided the original work is properly cited. 
additional dilemma of environment pollutions due to the heavy dependency on fossil fuels and biomass [1]. Biogas is a flammable gas produced when organic materials are fermented under anaerobic condition [2, 3]. It holds promise as an alternative energy source capable of being used for generating electricity, car fueling, cooking among others [4]. The rate of biogas production depends on the nature of the substrate, temperature, $\mathrm{pH}$, loading rate, toxicity, stirring, nutrients, slurry concentration, digester construction and size, carbon to nitrogen ratio, retention time, alkalinity, initial feeding, total volatile acids, chemical oxygen demand (COD), biological oxygen demand (BOD), total solids (TS), and volatile liquids among others [5].

Biomass such as agricultural wastes, municipal waste, and green waste (kitchen waste) present a promising renewable energy opportunity [6]. In most cities in Nigeria, waste is disposed off as landfills or discarded indiscriminately which causes health hazard and diseases like malaria, typhoid, and cholera [7], hence biological conversion of biomass to methane has received an increasing attention in recent years. Over the years, several techniques have been used for the conversion of organic materials to biogas but anaerobic digestion has gained prominence over the years. The anaerobic digestion process involves four stages namely: hydrolysis, acidogenesis, acetogenesis and methanogenesis [8-11] with each stage carried out by consortia of microorganisms which partly stand in syntrophic interrelation [12].

Agricultural wastes have become an integral source of biogas production especially in areas where agriculture forms an important part of the economy [13]. These wastes not only lead to soil loss and farmland damages if left unchecked but could pose danger to health of the populace especially if they litter the environment as they are known to be perfect habitat for pathogenic microorganism. This paper hence presents results of the production of biogas from fresh, dried and cow-seeded pumpkin residue as well as ascertaining the microbial consortia implicated in the biogas production.

\section{Materials and Methods}

\section{Study location}

The experiment was conducted at the Sokoto Energy Research Centre (SERC) central laboratory, Usmanu Danfodiyo University (13.1246º N, 5.1994 E) Sokoto, Sokoto State Nigeria. 


\section{Source of sample}

Pumpkin residues were collected from different fruit seller locations within Sokoto metropolis while cow (Bos primigenius) dung was collected from Dundaye village both in Sokoto metropolis.

\section{Media used}

Starch agar, carboxymethyl cellulose agar, egg yolk agar and nutrient-gelatin agar (Biotech Lab Ltd, UK) and triple sugar Iron agar (Hardy Diagnostic, USA) were the media used for the study.

\section{Preparation of media and reagents}

All the media and reagents used were prepared and preserved according to the manufacturer's specifications.

\section{Digester design}

Cylindrical cans were used as the digesters and plastic basins were used as water trough. To each can, a hole was bored on the lid of the can and a polyvinyl chloride tube was inserted into the hole and fixed with araldite adhesive to ensure that the digester was airtight. This served as the outlet for the generated biogas. The free end of the rubber tube was then inserted, through water contained in a partly filled water trough into an inverted measuring cylinder that has also been filled with water, to serve as the biogas collection system. The biogas was collected by downward displacement of water.

\section{Preparation of slurry and loading of digesters}

Both wastes were collected fresh, chopped by hand into small pieces (2-3 mm length) and sorted into three portions. The fresh portion was dried from two week before being reduced to fine powder with the aid of mortar and pestle. Its slurry was prepared by macerating the dried substrate with distilled water in the ratio of 1:4. While, the second portion was finely grounded with water in an electric milling machine in the ratio 1:4, the third portion was seeded with cow dung in the ratio 1:6 water to waste (ratio arrived at after preliminary trial). The slurries were quickly loaded into their respective biodigesters. Each sample category was performed in triplicate.

\section{Preparation of spent slurries for microbial isolation}

$10 \mathrm{~g}$ of the spent slurries were weighed and aseptically crushed into homogenous mixture. It was transferred into $90 \mathrm{ml}$ of sterile distilled water contained in a $100 \mathrm{ml}$ volumetric flask. The mixture was agitated and allowed to settle. 


\section{Isolation and assessment of bacterial populations}

The method described by Aderonke et al. [14] was adopted with slight modification. The prepared substrates correspond to 10-1 dilution. $10 \mathrm{ml}$ of aliquot from the 10-1 dilution was measured into another volumetric flask containing $90 \mathrm{ml}$ of sterile distilled water to obtain 10-2dilution. Further dilutions were carried out until a dilution level of 10-7 was reached. Samples were taken once every three days for total heterotrophic counts. For bacterial screening, dilutions 10-5to 10-7 of the samples (upon serial dilution) were plated on starch agar, carboxymethyl celluloseagar, egg yolk agar and nutrientgelatin agar (hydrolytic bacteria media). Plates were incubated for 48 hours at $35^{\circ} \mathrm{C}$. Colony forming units per gram (CFU g ${ }^{-1}$ ) of bacterial growth between 30-300 colonies were enumerated. The colonies formed were sub cultured and identified using cultural, morphological and biochemical methods.

\section{Characterization of the isolates}

Cultural and morphological characteristics of pure colonies were used to perform preliminary characterization [15]. The cell shape and arrangement characteristics were viewed under compound microscope after standard staining. 3\% (w/v) $\mathrm{KOH}$ test [16] was used to determine the gram characteristics of the isolates. Among the biochemical tests conducted were catalase, coagulase, lactose, glucose, sucrose, citrate, indole, $\mathrm{H}_{2} \mathrm{~S}$ production, urease, gas, methyl red (MR), Voges-proskaeur (VP), spore formation, oxidase and motility tests

\section{Measurement of gas production}

Biogas production was measured daily on volume basis as evidenced by the displacement of water in the inverted measuring cylinder that has been filled with water to serve as the biogas collection system

\section{Statistical Analysis}

Statistical analysis of data obtained from the different treatments were carried out using student t-test and analysis of variance (ANOVA). All data were expressed as means \pm standard deviation of triplicate trials.

\section{Results and Discussion}

\section{Daily biogas production}

This research work was done during the dry season with a temperature range of $30-$ 
$34^{\circ} \mathrm{C}$ and during the 35 day retention time. Figures 1 and 2 show the daily biogas production of the fresh pumpkin substrate and weekly volume of biogas produced by the fresh, dried and cow dung seeded pumpkin substrate.

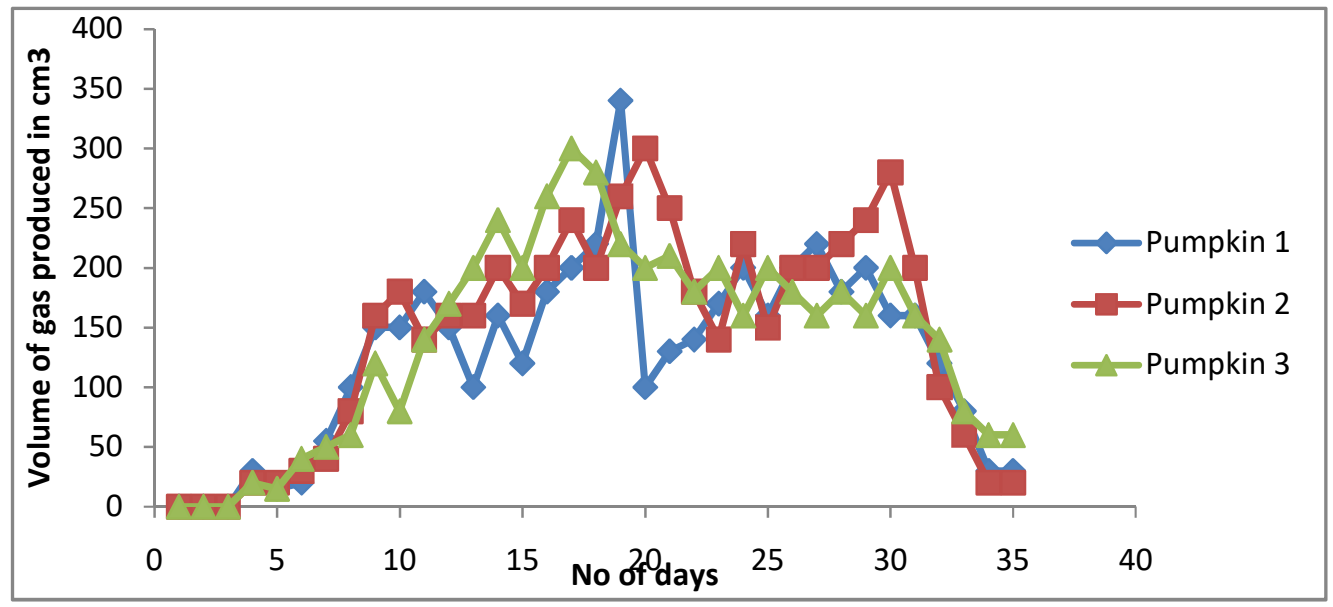

Figure 1. Daily biogas produced from pumpkin substrate throughout the retention period.

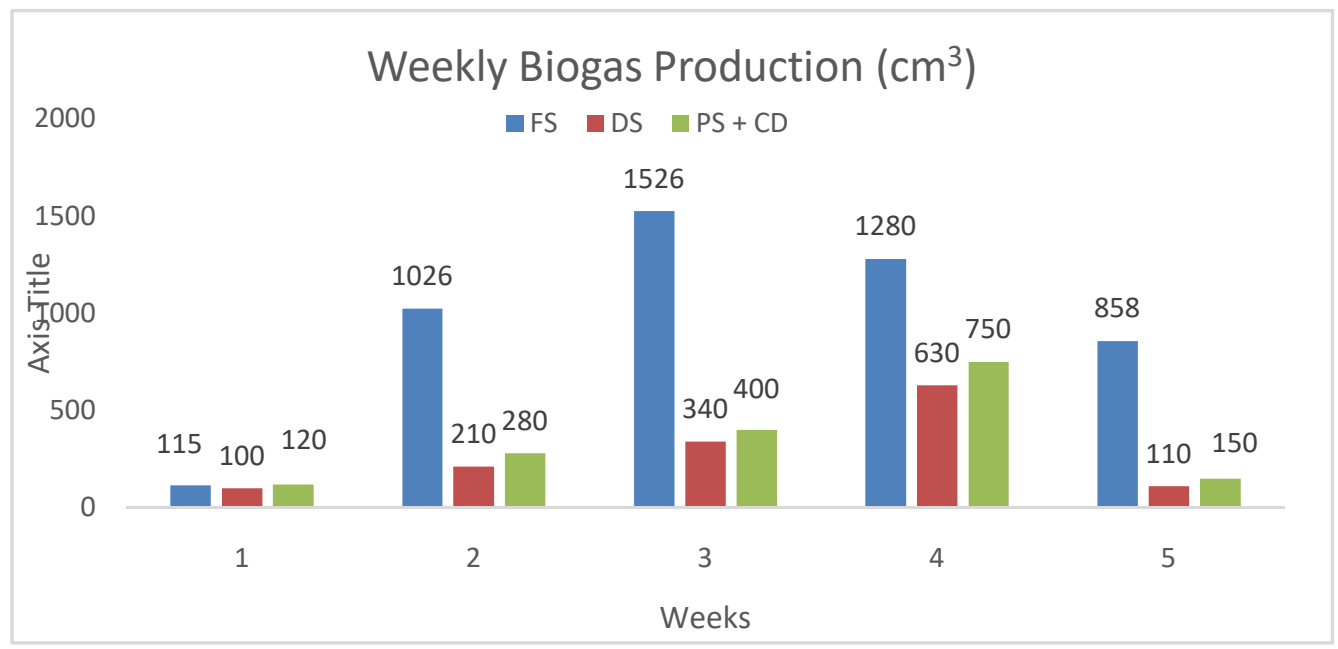

Figure 2. Weekly Biogas Production.

Key: $\mathrm{FS}=$ Fresh substrate; DS $=$ Dried substrate $; \mathrm{PS}+\mathrm{CD}=$ Pumpkin substrate seeded with cow dung.

The results presented in Figure 2 showed that the fresh substrate produced the highest volume of biogas produced when compared with the dried sample as well as that coseeded with cow dung. This findings contradicts the acknowledged fact that cow dung is 
the best biogas producer amongst animal wastes when blended with suitable substrates as a result of the rich flora of microorganism supplied by the animal waste which is capable of hydrolyzing a large amount of polysaccharide, which includes starch and biodegradable organic matter compared to the fresh and dried substrates when used independently [17]. The digester containing the fresh substrates produces more biogas than their dried counterpart. This may be because of a tougher lignin, cellulose and hemicelluloses in the dried sample as suggested by Adelekan and Bamgboye [18], who reported that lignin suppresses biodegradation and the higher the lignin content, the lower the biogas yield. The decline in the volume of biogas produced in weeks 4 and 5 when compared to week 3 when the volume of biogas peaked could be attributed to the decline in $\mathrm{pH}$ and increase in temperature of the medium, deposition of microbial metabolites (results not presented) as well as the gradual exhaustion of available nutrient from the substrates [19].

Figure 3 shows the calorific value of the produced biogas from the pumpkin substrate in comparison with established briquettes.

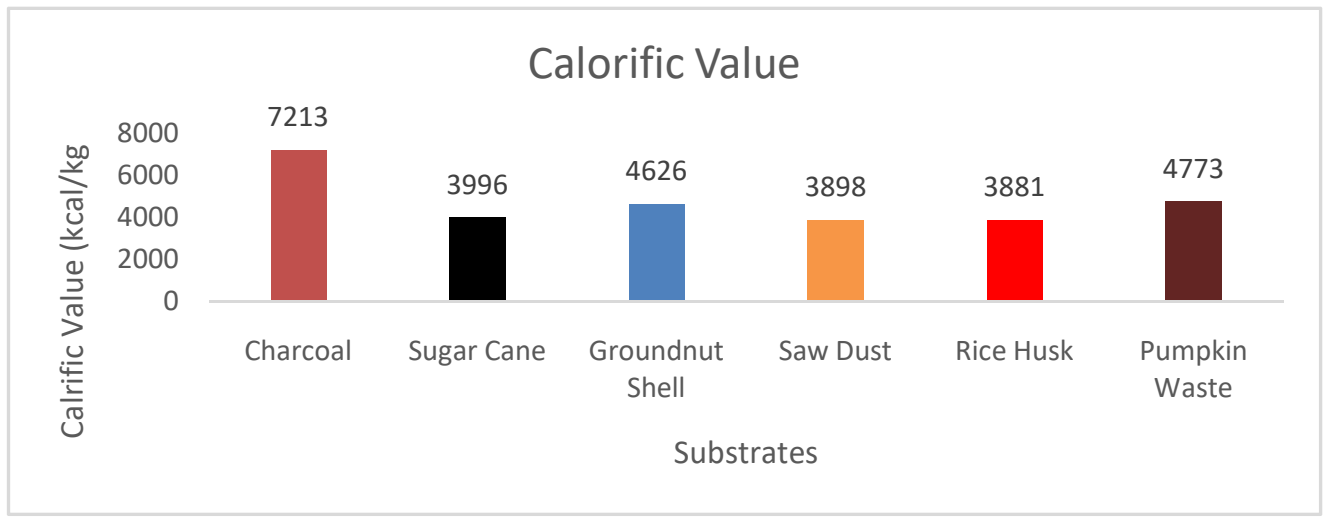

Figure 3. Calorific value of the produced biogas from pumpkin residue in comparison with conventional briquettes (Harban et al. [20]).

One of the most important characteristics of a fuel is its calorific value, that is the amount of energy per $\mathrm{kg}$ it gives off when burnt. The calorific value can thus be used to determine the competitiveness of a processed fuel in a given market situation in addition to other factors like the ease of handling, burning characteristics among others [20]. The reported calorific values of the sample if dried, blended and made as briquette will have good heating ability and compared reasonably with established briquettes as reported by Harbans et al. [20]. 


\section{Morphological and biochemical characterization of the isolated microbial isolates}

Tables 1 and 2 presents the morphological and biochemical characterization of the bacteria isolates.

Table 1. Morphological characteristics of bacteria isolates obtained from the substrates

\begin{tabular}{|c|c|c|c|c|c|c|}
\hline \multirow{2}{*}{ Substrate } & \multirow{2}{*}{ Isolate } & \multicolumn{2}{|c|}{ Colony Morphology } & \multirow{2}{*}{$\begin{array}{c}\text { Gram } \\
\text { Reaction }\end{array}$} & \multicolumn{2}{|c|}{ Cell Morphology } \\
\cline { 3 - 4 } \cline { 6 - 7 } & & Colour & Form & Arrangement & Motility \\
\hline \multirow{2}{*}{$\begin{array}{c}\text { Pumpkin } \\
\text { Residue }\end{array}$} & $\mathrm{PU}^{1}$ & Grey & Rod & - & $\operatorname{Rod}$ & + \\
\cline { 3 - 4 } & $\mathrm{PU}^{2}$ & Off-white & Rod & + & $\operatorname{Rod}$ & - \\
\hline
\end{tabular}

Table 2. Biochemical characterization of the bacteria isolates obtained from the substrates

\begin{tabular}{|c|c|c|}
\hline \multirow[t]{2}{*}{ Substrate/Test } & \multicolumn{2}{|c|}{ Pumpkin Residue } \\
\hline & $\mathrm{PU}^{1}$ & $\mathrm{PU}^{2}$ \\
\hline Catalase & - & - \\
\hline Coagulase & + & - \\
\hline Lactose & + & - \\
\hline Glucose & + & - \\
\hline Fructose & + & - \\
\hline Citrate & + & - \\
\hline Indole & + & - \\
\hline $\mathrm{H}_{2} \mathrm{~S}$ & + & - \\
\hline Urease & + & - \\
\hline Gas & - & - \\
\hline MR & - & - \\
\hline $\mathrm{VP}$ & - & - \\
\hline Spore & - & - \\
\hline Oxidase & + & + \\
\hline Bacteria Isolated & ES & $\mathrm{EC}$ \\
\hline
\end{tabular}

Key: $(+)=$ Positive, $(-)=$ Negative, $\mathrm{ES}=$ Enterobacterspp, $\mathrm{EC}=$ Escherichia coli, $\mathrm{PU}=$ Pumpkin. 
Jaenicke et al. [21] reported that members of methanogens frequently dominate methanogenic sub-communities in different anaerobic digester systems and this research has shown that different methanogenic sub-communities within biogas producing consortia are crucial in the anaerobic degradation process for synthesis of methane. The bacteria isolated from the pumpkin residue is in agreement with the findings of Demirel and Scherer [22] who reported that the anaerobic transformation of organic wastes is a process which involves many different groups of bacteria such as hydrolyzing, acidifying, acetogenic and methanogenic bacteria which in the final stage produce $\mathrm{CO}_{2}$ and methane, which are the main products of the digestion process.

\section{Conclusion}

This research confirms that the organic waste materials from pumpkin fruit can be utilized by microorganisms for biogas production. The usage of this substrate for biogas production is possible due to the accessibility by cellulolytic, lipolytic, proteolytic and amylolectic microorganisms which play a vital role in biogas production from organic wastes.

\section{References}

[1] A.M. Mshandete, and W. Biogas Parawira, Technology Research in selected sub-Saharan African, African Journal of Biotechnology 8(2) (2009), 116-125.

[2] S. Baba, U. Shedu, I. Abubakar, and I. Nasir, Anaerobic digestion of cow dung for biogas production, ARPN Journal of Engineering and Applied Sciences 7 (2012), 169-172.

[3] S. Ezeohu, I. Dioha and N. Eboatu, Daily biogas production from different wastes and identification of methanogenic bacteria involved, Nigerian Journal of Solar Energy 15 (2005), 80-85.

[4] C. Madu and O. Sodeinde, Relevance of biomass in the sustainable energy development in Nigeria, Proceedings of the National Engineering Conference and Annual General Meeting of the Nigerian Society of Engineers (2001), 220-227

[5] A.A. Biogas Abubakar, Potential of some selected kitchen wastes within Kaduna metropolis, American Journal of Engineering Research 6 (5) (2017), 53-63.

[6] B.S. Sagagi, B. Garba and N.S. Usman, Studies on biogas production from fruits and vegetable waste, Bayero Journal of Pure and Applied Sciences 2(1) (2009), 115-118. https://doi.org/10.4314/bajopas.v2i1.58513

[7] O.L. Adeyosoye, L.A. Adesokan, K.D. Afolabi and A.H. Ekeocha, Estimation of 
proximate composition and biogas production from in vitro gas fermentation of sweet potatoe and wild cocoyam peels, African Journal of Environmental Science and Technology 4(6) (2010), 388-391.

[8] G. Bitton, Wastewater Microbiology, A John Wiley \& Sons Inc. Publication, 3rd ed., Hoboken, New Jersey Chap. 13, 2005, pp. 345-369.

[9] M.H. Gerardi, Wastewater Microbiology Series: The Microbiology of Anaerobic Digesters, John Wiley and Sons, Inc., New York, 2003.

https://doi.org/10.1002/0471468967

[10] C.O. Nwuche and E.O. Ugoji, Effects of heavy metal pollution on the soil microbial activity, Int. J. Environ. Sci. Technol. 5(3) (2008), 409-414.

https://doi.org/10.1007/bf03326036

[11] C. O. Nwuche and E. O. Ugoji, Effect of co-existing plant specie on soil microbial activity under heavy metal stress, Int. J. Environ. Sci. Technol. 7(4) (2010), 697-704. https://doi.org/10.1007/bf03326179

[12] I. Angelidaki, L. Ellegaard and B.K. Ahring, A mathematical model for dynamic simulation of anaerobic digestion of complex substrates: focusing on ammonia inhibition, Biotechnology and Bioengineering 42 (1993), 159-166.

https://doi.org/10.1002/bit.260420203

[13] B. Garba, A. Zuru and A.S. Sambo, Effect of slurry concentration on biogas concentration from cattle dung, Nigeria Journal of Renewable Energy 4 (1996), 38-43.

[14] A. Aderonke, A. Wasiu and O. Moses, Isolation and characterization of microorganisms with hydrolytic profile during anaerobic digestion and biogas production of cow dung and rice husk, Journal of Natural Sciences Research 7(5) (2017), 20-30

[15] J.G. Holt, N.R. Krieg, P.H.A. Sneath, J.T. Stanley and S.T. Williams, Bergey's Manual of Determinative Bacteriology, 9th ed., Williams \& Wilikins, Baltimore, 1994.

[16] T. Gregersen, Rapid method for distinction of gram-negative from gram-positive bacteria, European J. Appl. Micobiol. Biotechnol. 5(2) (1978), 123-127. https://doi.org/10.1007/bf00498806

[17] O. Odeyemi, Biogas generation from cassava leaves compared with two animal manures and sewage sludge, Review in: Energy in Biogas Industries, Pergamon Press, Oxford, 2004, pp. 554-558.

[18] B.A. Adelekan, and A.I. Bamgboye, Comparison of biogas productivity of cassava peels mixed in selected ratios with major livestock waste types, African J. Agric. Research 4(7) (2009), 571-577. 
[19] B.E. Asikong, S.O. Idire and D.R. Tiku, Microorganisms associated with biogas production using vegetable (Telfairia occidentalis) wastes, banana peel and pig dung as substrates, British Microbiology Research Journal 16(3) (2016), 1-12. https://doi.org/10.9734/bmrj/2016/28294

[20] S. Harban, S. Sarabjit and S. Sukhwinder, Calorific Value of Briquettes from Various Raw Materials for Fuel, 2013, pp. 760-766.

[21] S. Jaenicke, C. Ander, T. Bekel, R. Bisdorf, M. Dröge, K.-H. Gartemann et al., Comparative and joint analysis of two metagenomic datasets from a biogas fermenter obtained by 454-phyrosequencing, PLOS ONE 6(1) (2011), e14519.

https://doi.org/10.1371/journal.pone.0014519

[22] B. Demirel and P. Scherer, The roles of acetotrophic and hydrogenotrophic methanogens during anaerobic conversion of biomass of methane, Rev. Environ. Sci. Biotechnol. 7 (2008), 173-190. https://doi.org/10.1007/s11157-008-9131-1 